\title{
Topical Calcipotriol versus oral vitamin $D$ in the treatment of alopecia areata
}

\author{
Talal A. Abd-ElRaheem ${ }^{(1)}$, Basma H. Mohammed ${ }^{(1)}$, Hassan S. El-Sayed ${ }^{(2)}$, and \\ Sara Kh.A. Ahmed ${ }^{(1)}$.
}

(1) Dermatology, STDs and Andrology department, Faculty of Medicine Fayoum University

(2) Biochemistry department, Faculty of Medicine- Fayoum University

Corresponding author: prof .Talal A. Abd-ElRaheem

E-mail address: talasam@yahoo.com

Tel:01006600360

Fax: +2084636583

\begin{abstract}
Background: Alopecia areata (AA) is non-scarring hair loss resulting from an autoimmune disorder. Severity varies from patchy hair loss that often spontaneously resolves to severe and chronic cases that can progress to total loss of scalp and body hair.

Aim of the work: To compare the efficacy of topical calcipotriol versus oral vitamin D in alopecia areata.

Patient and Methods: Fifty patients having localized alopecia ( $<5$ patches and $<40 \%$ scalp involvement) were treated with topical calcipotriol $0.005 \%$ twice daily for 3 months (group 1) and oral vitamin D daily for 3 months (group 2). All cases were assessed by grading the degree of improvement of alopecia and dermoscopic evaluation. Estimation of serum levels of 25-hydroxy vitamin D in all patients before the treatment.
\end{abstract}

\section{Keywords:}

\section{Alopecia areata-Topical calcipotriol-Oral vitamin D.}

\section{INTRODUCTION:}

Alopecia areata (AA) is a complex genetic, immune mediated disease that targets anagen hair follicles (Hordinsky, 2013). It is a common, nonscarring,
Results: There was statistically significant difference with p-value $<0.05$ between two study groups regarding to degree of improvement. Dermoscopic findings that explain signs of activity were decreased, and signs of improvement were appeared after 3rd months of treatment. In topical calcipotriol group terminal hair was more than oral vitamin D group, in which signs of activity was still present in some cases. Conclusion: In conclusion, topical calcipotriol (68\% improvement) was better than oral vitamin $\mathrm{D}$ in the treatment of mild and moderate alopecia areata. There is no releation between serum vitamin D and efficacy of treatment. However, further studies on larger scales are required to identify the vitamin D receptor deficiency in alopecia areata.

autoimmune disease that can affect any hair- bearing area (Alsantali, 2011). 
The disease affects children and adults and is characterized by round or oval patches of scalp hair loss, total scalp hair loss (alopecia totalis), universal loss of all hairs (alopecia universalis) (Hordinsky, 2013), or ophiasis pattern which is snakeshaped hair loss around the circumference of the head in the temporal, occipital and frontal areas (Brzezińska-Wcisło et al., 2014).

The treatment of AA may take a long time which is not less than 3 months or more, and in some cases till there is a good and accepted hair regrowth. In most cases there is a need for the combination therapy. Most methods of treatment usually begin with use of one drug with low side effects, then the use of another drug or more, depending on a lot of points. One of those points that considered as the most important one is the severity of the disease (GalánGutiérrez et al., 2009).

Vitamin D plays several roles in the body, influencing bone health as well as serum calcium and phosphate levels. Furthermore, vitamin D may modify immune function, cell proliferation, differentiation, and apoptosis (Dastani et al., 2012).

Various immunological cells such as monocytes, $\mathrm{T}$ and $\mathrm{B}$ lymphocytes and Langerhans cells express both vitamin $\mathrm{D}$ receptor and $1 \alpha$-hydroxylase implicating a vital role of vitamin $D$ in control and regulation of immune mechanisms (Wadhwa et al., 2015). Recently, a connection between some autoimmune diseases and vitamin D deficiency has been reported, and vitamin D deficiency was suggested to act as an environmental trigger for the induction of autoimmunity (D'Aurizio et al., 2015).

Reports have highlighted serum vitamin $D$ deficiency and reduced 1,25dihydroxyvitamin $\mathrm{D}(3)$ receptors (VDR) expression on hair follicles of alopecia areata (AA) patients (Naranq et al.,
2017). Deficient serum $25(\mathrm{OH})$ D levels are present in patients with AA and inversely correlate with disease severity. Accordingly, screening patients with AA for vitamin $D$ deficiencies seems to be of value for the possibility of supplementing these patients with vitamin D (Çerman, 2015).

Calcipotriol is a vitamin D analogue and a potent immunomodulatuary molecule. It may serve as a safe and effective treatment option in mild-to-moderate patchy AA (Çerman et al., 2015).

\section{Patients and methods:}

It was a prospective cohort, that included 50 patients with localized alopecia areata. Two groups were involved: 25 patients used topical calcipotriol $(0.005 \%)$ cream twice daily for 3 months $\} 12$ (48\%) males and $13(52 \%)$ females\& their ages ranged from 3 to 35 years, median $7\{$ as a group 1. Their Family history was positive in $12 \%$ of patients. One had past history of trauma/ hospitalization. Drug history was negative in $60 \%$ of patients, $20 \%$ had history of drug intake without improvement, $12 \%$ with improvement and $8 \%$ with recurrence. None of patients had chronic illnesses or autoimmune disorders and $20 \%$ had associated skin disorders, $64 \%$ of patients had only one bald patch, $28 \%$ had two patches, $4 \%$ had three patches and $4 \%$ had four patches. The distribution of patches in the scalp ranged from $2 \%$ to $7.5 \%$. Majority of patients had the disease for not more than five months with sudden onset in $84 \%$ of cases and progressive course in $64 \%$ of cases., and 25 patients received oral vitamin D (1 microgram) cap once daily for 3 months 39 (36\%) males and 16 (64\%) females\& their ages ranged from 7 to 40 years, median 9 \{ as a group 2. Their Family history was positive in $20 \%$ of patients. One had past history of surgery/hospitalization. Drug history was negative in $72 \%$ of patients, $16 \%$ had history of drug intake without 
improvement, $8 \%$ with improvement and $4 \%$ with recurrence. None of patients had chronic illnesses or autoimmune disorders and $16 \%$ had associated skin disorders. $72 \%$ of patients had only one bald patch, $16 \%$ had two patches, $8 \%$ had three patches and $4 \%$ had seven patches. The distribution of patchs in the scalp ranged from $2 \%$ to $7 \%$. Majority of patients had the disease for not more than six months with sudden onset in $88 \%$ of cases and progressive course in $60 \%$ of cases. Patient selection included a written consent. The study plan considering this work was accepted by the Ethical committee of Faculty of Medicine, Fayoum University, for participation in the study. We excluded severe cases as alopecia totalis, universalis and ophiasis, pregnant and lactating women, Contraindications to topical calcipotriol as allergic reactions, hypercalcimia, hypervitaminosis D, severe liver and kidney diseases and contraindication to oral vitamin D intake as sarcoidosis, hyperphosphatemia, hypercalcemia, arteriosclerosis and thrombi, renal stone and renal diseases. All the patients were subjected to detailed history taking, dermatological examination to detect type and severity of alopecia areata (localized or diffuse) and distribution of lesions, dermoscopic examination SCALAR CORPORATION, made in Japan, was intented for confirm the diagnosis and detect activity of alopecia areata, estimation of serum levels of 25-hydroxy vitamin $\mathrm{D}$ in all patients before the treatment and a photograph was taken before starting treatment (baseline), during the three months of treatment period\& 3 months post stoppage of treatment to detect recurrence.

Follow up was done at monthly intervals for three months and three months post stoppage of treatment, in each visit the patient was asked for compliance, satisfaction and side effects of the treatment.

Response to treatment was be evaluated:

- Subjectively by grading the degree of improvement into 6 degrees: No response $(0 \%)$, Poor response $(0-20 \%)$, Some response (20-40\%), Good response (40$60 \%)$, Very good response (60-90\%) and Full regrowth (100\%).

- Objectively by patient satisfaction.

- By dermoscopy at each time to evaluate the results as signs of activity and improvement.

\section{RESULTS:}

There was no statistically significant difference between topical calcipotriol cream and oral vitamin D regarding degree of improvement of alopecia after $1^{\text {st }}$ month, while there was statistically significant difference between topical calcipotriol cream and oral vitamin D regarding degree of improvement after $2^{\text {nd }}$ and $3^{\text {rd }}$ months $(\mathrm{p}>0.05)$ (table $1 \&$ figure $1,2,3$ ).

Table (1): Comparison between Topical calcipotriol cream and oral vitamin D regarding to degree of improvement of alopecia after first, second and third months of treatment

\begin{tabular}{|l|l|l|l|l|}
\hline \multirow{2}{*}{} & \multicolumn{2}{|l|}{ Group } & $\begin{array}{l}\text { Chi } \\
\text { square }\end{array}$ & P value \\
\cline { 2 - 3 } & $\begin{array}{l}\text { Topical } \\
\text { calcipotriol } \\
\text { cream }\end{array}$ & $\begin{array}{l}\text { oral } \\
\text { vitami } \\
\text { n D }\end{array}$ & \\
& & \\
\hline
\end{tabular}


ISSN: 2536-9474 (Print)

ISSN: 2536-9482 (Online) Fayoum University Medical Journal al.,2019,2(1),47-58
Original article / FYMJ

Abd-ElRaheem et

\begin{tabular}{|c|c|c|c|c|c|c|}
\hline \multirow{12}{*}{$\begin{array}{l}\text { Degree of } \\
\text { improvement after } 1^{\text {st }} \\
\text { month: }\end{array}$} & \multirow[t]{2}{*}{$\begin{array}{l}\text { No } \\
\text { response }\end{array}$} & $\mathrm{N}$ & 7 & 6 & \multirow[t]{12}{*}{4.213} & \multirow[t]{12}{*}{$\begin{array}{l}0.239 \\
\text { ns }\end{array}$} \\
\hline & & $\%$ & $28.0 \%$ & $24.0 \%$ & & \\
\hline & \multirow{2}{*}{$\begin{array}{l}\text { Poor } \\
\text { response }\end{array}$} & $\mathrm{N}$ & 1 & 6 & & \\
\hline & & $\%$ & $4.0 \%$ & $24.0 \%$ & & \\
\hline & \multirow[t]{2}{*}{$\begin{array}{l}\text { Some } \\
\text { response }\end{array}$} & $\mathrm{N}$ & 11 & 8 & & \\
\hline & & $\%$ & $44.0 \%$ & $32.0 \%$ & & \\
\hline & \multirow{2}{*}{$\begin{array}{l}\text { Good } \\
\text { response }\end{array}$} & $\mathrm{N}$ & 6 & 5 & & \\
\hline & & $\%$ & $24.0 \%$ & $20.0 \%$ & & \\
\hline & \multirow{2}{*}{$\begin{array}{l}\text { Very } \\
\text { good } \\
\text { response }\end{array}$} & $\mathrm{N}$ & 0 & 0 & & \\
\hline & & $\%$ & $0 \%$ & $0 \%$ & & \\
\hline & \multirow{2}{*}{$\begin{array}{l}\text { Full } \\
\text { regrowth }\end{array}$} & $\mathrm{N}$ & 0 & 0 & & \\
\hline & & $\%$ & $0 \%$ & $0 \%$ & & \\
\hline \multirow{12}{*}{$\begin{array}{l}\text { Degree of improvement } \\
\text { after } 2^{\text {nd }} \text { month: }\end{array}$} & \multirow{2}{*}{$\begin{array}{l}\text { No } \\
\text { response }\end{array}$} & $\mathrm{N}$ & 7 & 5 & \multirow[t]{12}{*}{11.908} & \multirow[t]{12}{*}{$0.018 \mathrm{~S}$} \\
\hline & & $\%$ & $28.0 \%$ & $20.0 \%$ & & \\
\hline & \multirow{2}{*}{$\begin{array}{l}\text { Poor } \\
\text { response }\end{array}$} & $\mathrm{N}$ & 0 & 7 & & \\
\hline & & $\%$ & $0.0 \%$ & $28.0 \%$ & & \\
\hline & \multirow{2}{*}{$\begin{array}{l}\text { Some } \\
\text { response }\end{array}$} & $\mathrm{N}$ & 1 & 0 & & \\
\hline & & $\%$ & $4.0 \%$ & $0.0 \%$ & & \\
\hline & \multirow{2}{*}{$\begin{array}{l}\text { Good } \\
\text { response }\end{array}$} & $\mathrm{N}$ & 5 & 8 & & \\
\hline & & $\%$ & $20.0 \%$ & $32.0 \%$ & & \\
\hline & \multirow{2}{*}{$\begin{array}{l}\text { Very } \\
\text { good } \\
\text { response }\end{array}$} & $\mathrm{N}$ & 12 & 5 & & \\
\hline & & $\%$ & $48.0 \%$ & $20.0 \%$ & & \\
\hline & \multirow{2}{*}{$\begin{array}{l}\text { Full } \\
\text { regrowth }\end{array}$} & $\mathrm{N}$ & 0 & 0 & & \\
\hline & & $\%$ & $0 \%$ & $0 \%$ & & \\
\hline Degree of & No & $\mathrm{N}$ & 4 & 2 & 10.056 & $0.040 \mathrm{~S}$ \\
\hline
\end{tabular}


ISSN: 2536-9474 (Print)

ISSN: 2536-9482 (Online) Fayoum University Medical Journal
Original article / FYMJ

Abd-EIRaheem et

al.,2019,2(1),47-58

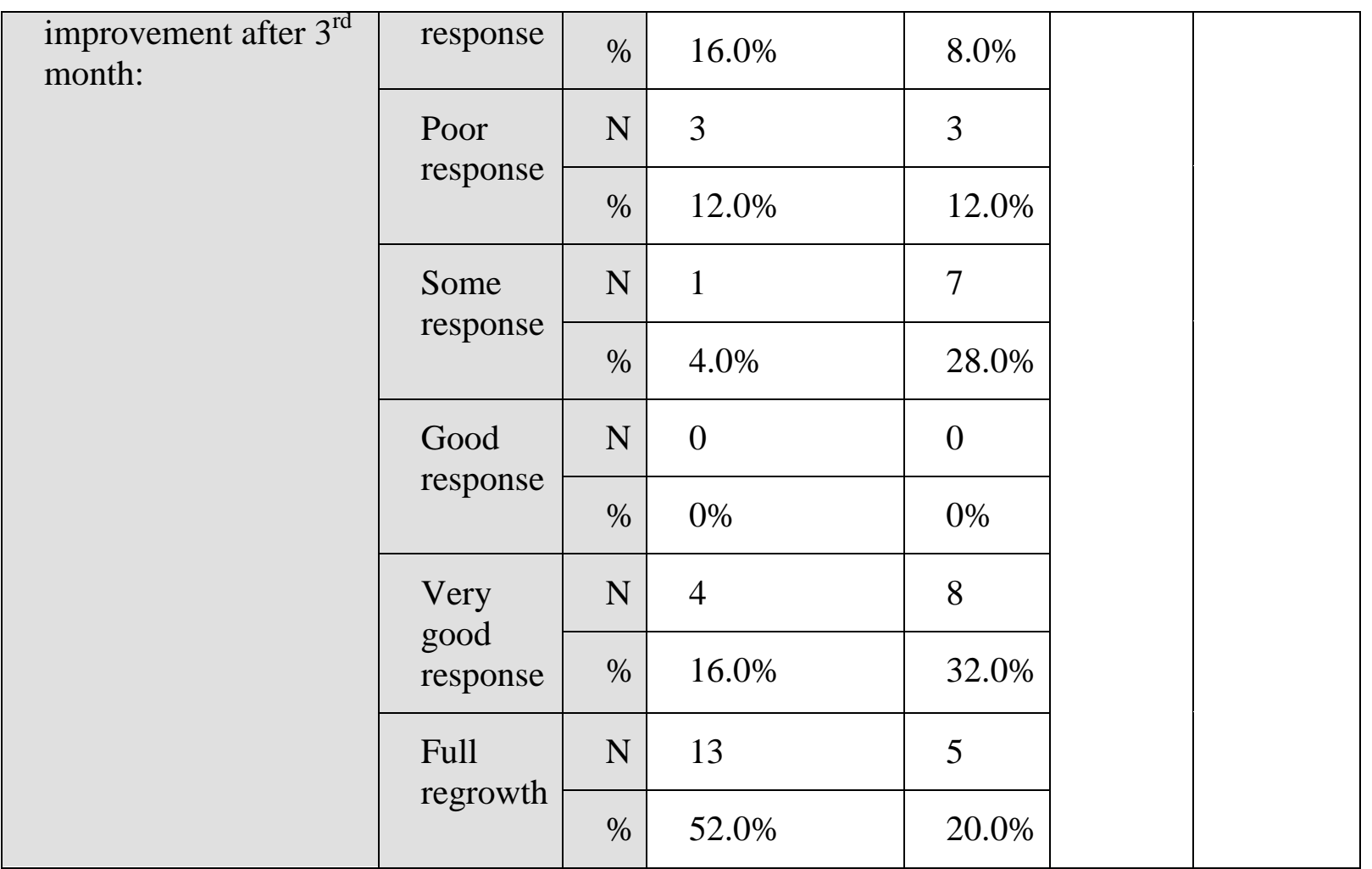

Ns $=$ non-significant at $\mathrm{p}$ value $>0.05, \mathrm{~S}=$ Significant at $\mathrm{p}$ value $<0.05$

\section{degree of improvement after first month}

No response $\quad$ Poor response $\quad$ Some response Good response

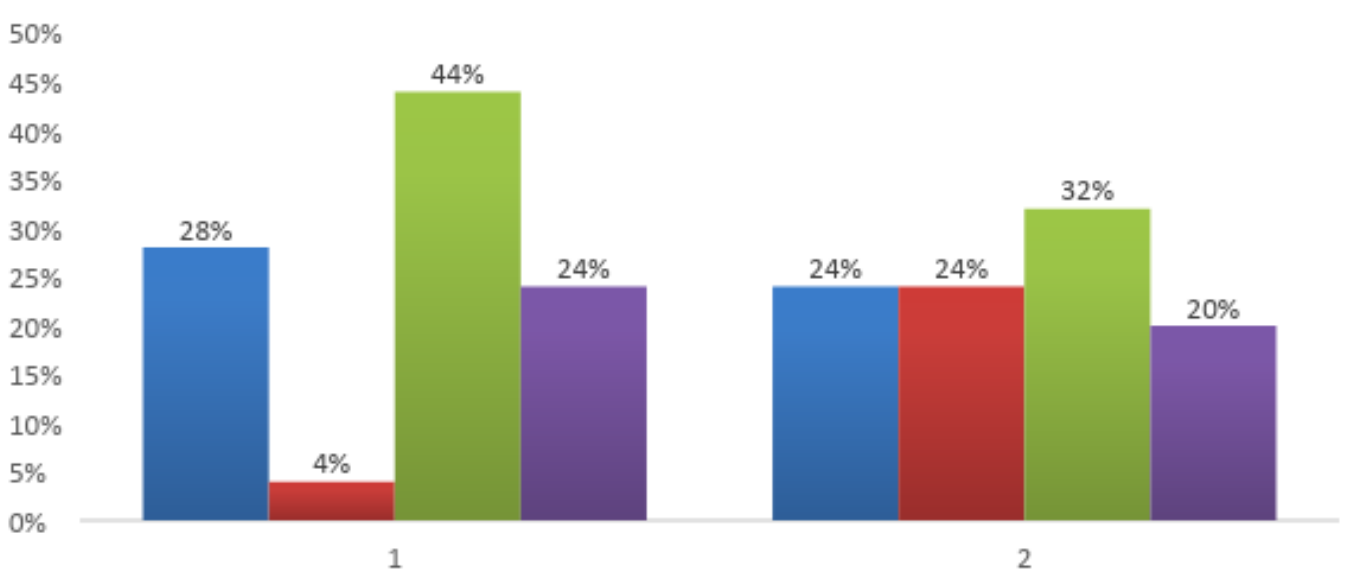

Fig. 1: Comparison between topical calcipotriol $0.005 \%$ cream and oral vitamin $D$ regarding the degree of improvement of alopecia after first month of treatment 


\section{degree of improvement after second month}
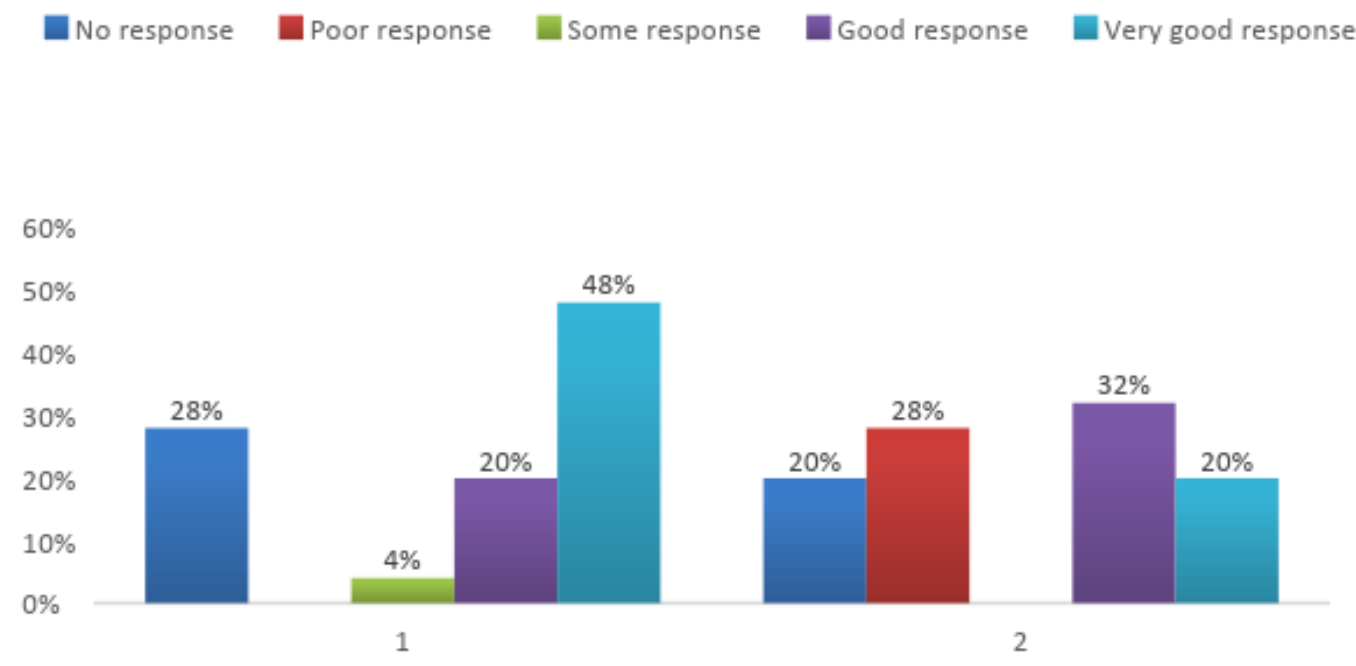

Fig. 2: Comparison between topical calcipotriol $0.005 \%$ cream and oral vitamin $D$ regarding the degree of improvement of alopecia after second month of treatment

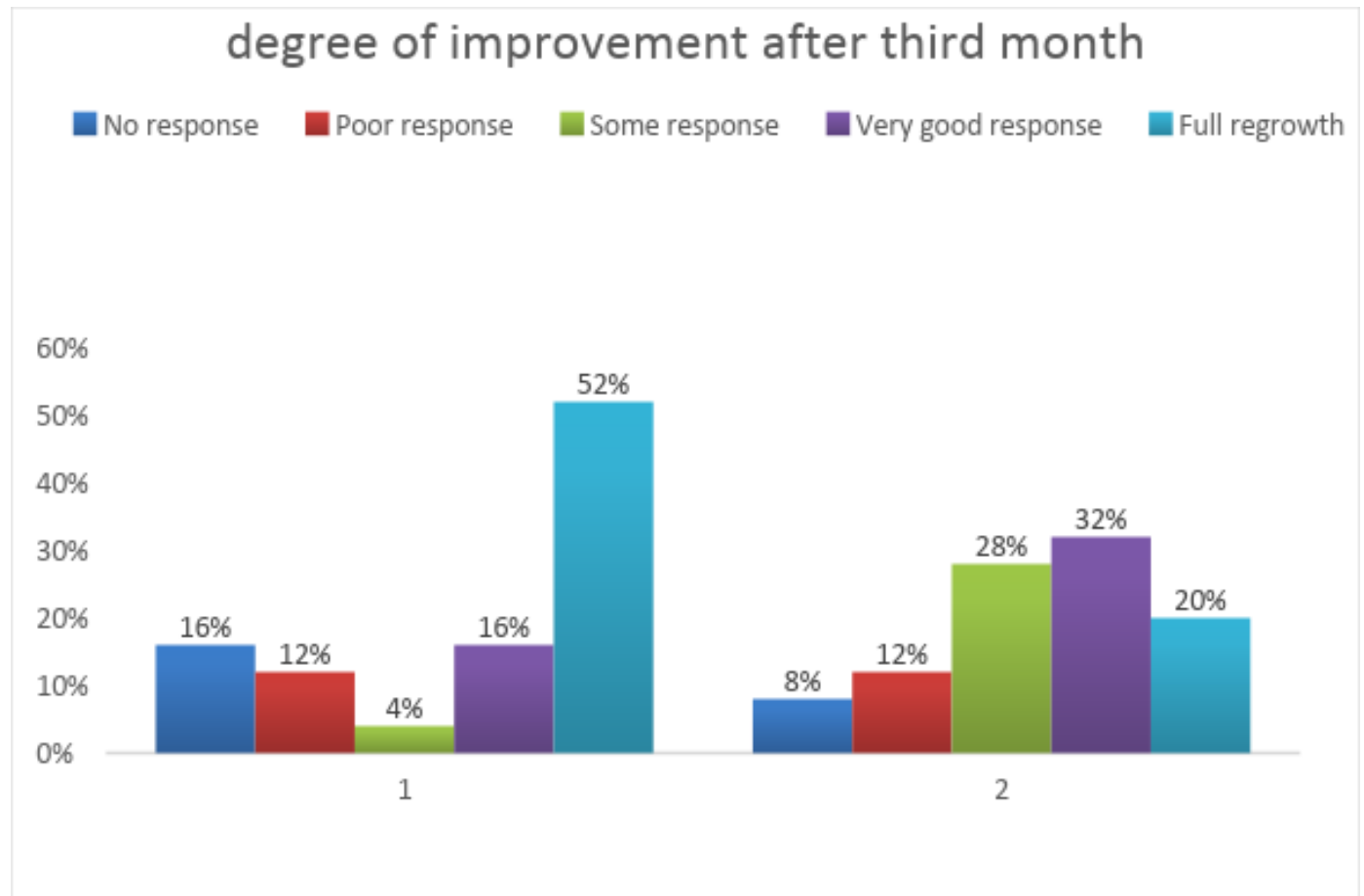

Fig. 3: Comparison between topical calcipotriol $0.005 \%$ cream and oral vitamin $D$ regarding degree of improvement of alopecia after third month of treatment

Dermoscopic findings at baseline, after first, second and third months of treatment was shown in (table 2). 
ISSN: 2536-9474 (Print)

ISSN: 2536-9482 (Online) Fayoum University Medical Journal
Original article / FYMJ

Abd-EIRaheem et

al.,2019,2(1),47-58

Table (2): Demographic data of the included persons regarding dermoscopic findings

\begin{tabular}{|c|c|c|c|c|c|}
\hline & & \multicolumn{2}{|c|}{$\begin{array}{l}\text { Topical calcipotriol } \\
0.005 \% \text { cream }\end{array}$} & \multicolumn{2}{|c|}{ Oral vitamin D } \\
\hline & & $\mathrm{N}$ & $\%$ & $\mathrm{~N}$ & $\%$ \\
\hline \multirow{6}{*}{ Baseline } & Black dots & 25 & 100 & 25 & 100 \\
\hline & $\begin{array}{l}\text { Yellow } \\
\text { dots }\end{array}$ & 19 & 76 & 20 & 80 \\
\hline & $\begin{array}{l}\text { Broken } \\
\text { hairs }\end{array}$ & 5 & 20 & 5 & 20 \\
\hline & $\begin{array}{l}\text { Tapering } \\
\text { hairs }\end{array}$ & 11 & 44 & 12 & 48 \\
\hline & $\begin{array}{l}\text { Short } \\
\text { vellus hair }\end{array}$ & 0 & 0 & 0 & 0 \\
\hline & $\begin{array}{l}\text { Terminal } \\
\text { hair }\end{array}$ & 0 & 0 & 0 & 0 \\
\hline \multirow[t]{6}{*}{$1^{\text {st }}$ month } & Black dots & 19 & 76 & 20 & 80 \\
\hline & $\begin{array}{l}\text { Yellow } \\
\text { dots }\end{array}$ & 19 & 76 & 17 & 68 \\
\hline & $\begin{array}{l}\text { Broken } \\
\text { hairs }\end{array}$ & 0 & 0 & 0 & 0 \\
\hline & $\begin{array}{l}\text { Tapering } \\
\text { hairs }\end{array}$ & 0 & 0 & 0 & 0 \\
\hline & $\begin{array}{l}\text { Short } \\
\text { vellus hair }\end{array}$ & 6 & 24 & 5 & 20 \\
\hline & $\begin{array}{l}\text { Terminal } \\
\text { hair }\end{array}$ & 0 & 0 & 0 & 0 \\
\hline \multirow[t]{6}{*}{$2^{\text {nd }}$ month } & Black dots & 7 & 28 & 7 & 28 \\
\hline & $\begin{array}{l}\text { Yellow } \\
\text { dots }\end{array}$ & 4 & 25 & 6 & 24 \\
\hline & $\begin{array}{l}\text { Broken } \\
\text { hairs }\end{array}$ & 0 & 0 & 0 & 0 \\
\hline & $\begin{array}{l}\text { Tapering } \\
\text { hairs }\end{array}$ & 0 & 0 & 0 & 0 \\
\hline & $\begin{array}{l}\text { Short } \\
\text { vellus hair }\end{array}$ & 6 & 25 & 8 & 32 \\
\hline & Terminal $\mathrm{h}$. & 12 & 48 & 5 & 20 \\
\hline \multirow[t]{6}{*}{$3^{\text {rd }}$ month } & Black dots & 4 & 16 & 5 & 20 \\
\hline & $\begin{array}{l}\text { Yellow } \\
\text { dots }\end{array}$ & 3 & 12 & 4 & 16 \\
\hline & $\begin{array}{l}\text { Broken } \\
\text { hairs }\end{array}$ & 0 & 0 & 0 & 0 \\
\hline & $\begin{array}{l}\text { Tapering } \\
\text { hairs }\end{array}$ & 0 & 0 & 2 & 8 \\
\hline & $\begin{array}{l}\text { Short } \\
\text { vellus hair }\end{array}$ & 15 & 60 & 10 & 40 \\
\hline & $\begin{array}{l}\text { Terminal } \\
\text { hair }\end{array}$ & 17 & 68 & 13 & 52 \\
\hline
\end{tabular}


Comparison between patients regarding to measurement of serum vitamin D (table 3\& figure 4).

Table (3): Comparison between patients regarding to measurement of serum vitamin D

\begin{tabular}{|l|l|l|l|}
\hline \multirow{3}{*}{ S. Vitamin D } & $<30$ & $\mathrm{~N}$ & 34 \\
\cline { 3 - 4 } & & $\%$ & $68.0 \%$ \\
\cline { 2 - 4 } & \multirow{2}{*}{$>30$} & $\mathrm{~N}$ & 16 \\
\cline { 3 - 4 } & & $\%$ & $32.0 \%$ \\
\hline
\end{tabular}

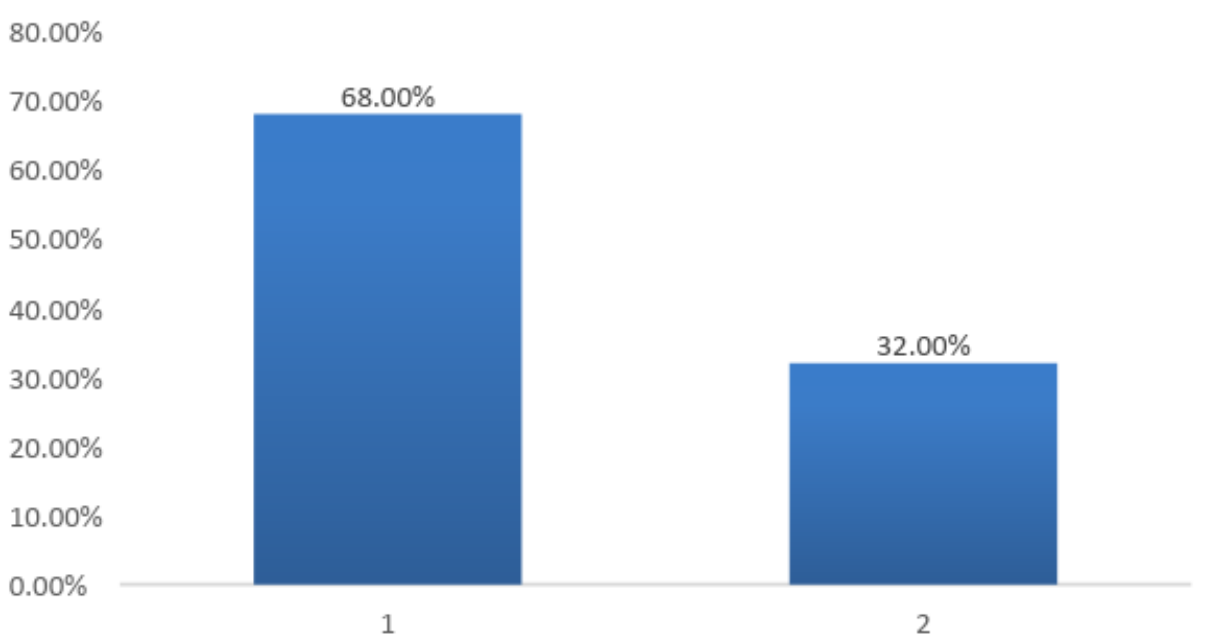

Fig. 4: Comparison between patients regarding to measurement of serum vitamin D

There was no statistically significant difference between degree of improvement of alopecia after third month regarding serum vitamin $\mathrm{D}$ in topical calcipotriol cream, serum vitamin $D$ in oral vitamin $D(p>0.05)$ (table $4 \&$ figure 5, 6).

Table (3): Comparison between degree of improvement after third month regarding to Serum vitamin $D$ in topical calcipotriol cream, Serum vitamin $D$ in oral vitamin D

\begin{tabular}{|l|l|l|l|}
\hline \multirow{2}{*}{$\begin{array}{l}\text { Degree of } \\
\text { improvement after 3 }\end{array}$} & $\begin{array}{l}\text { Serum vitamin D in } \\
\text { Topical calcipotriol } \\
0.005 \% \text { cream }\end{array}$ & $\begin{array}{l}\text { Serum vitamin } \\
\text { D in oral } \\
\text { vitamin D }\end{array}$ \\
\cline { 2 - 4 } & No response & $24.39 \pm 5.59$ & $30.05 \pm 1.34$ \\
\cline { 2 - 4 } & Poor response & $22.48 \pm 6.94$ & $28.94 \pm 6.47$ \\
\cline { 2 - 4 } & Some response & $17.03 \pm 0.00$ & $27.67 \pm 3.49$ \\
\cline { 2 - 4 } & $\begin{array}{l}\text { Very good } \\
\text { response }\end{array}$ & $24.72 \pm 5.26$ & $28.35 \pm 2.88$ \\
\cline { 2 - 4 } & Full regrowth & $24.97 \pm 6.36$ & $31.58 \pm 3.47$ \\
\hline F ratio & 0.456 & 0.973 \\
\hline P value & $0.767 \mathrm{~ns}$ & $0.444 \mathrm{~ns}$ \\
\hline
\end{tabular}




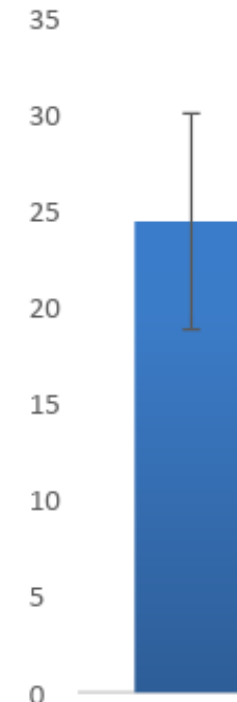

1

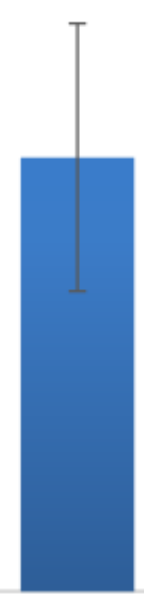

2

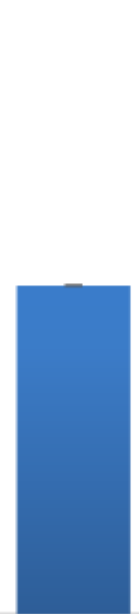

3

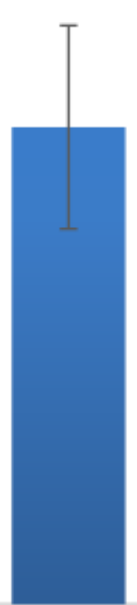

4

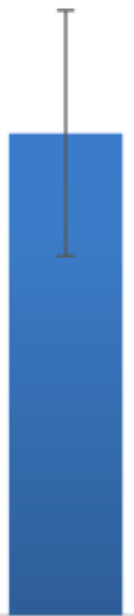

5

Figure (6): Comparison between degree of improvement after third month regarding to serum vitamin $D$ in topical calcipotriol $0.005 \%$ cream group

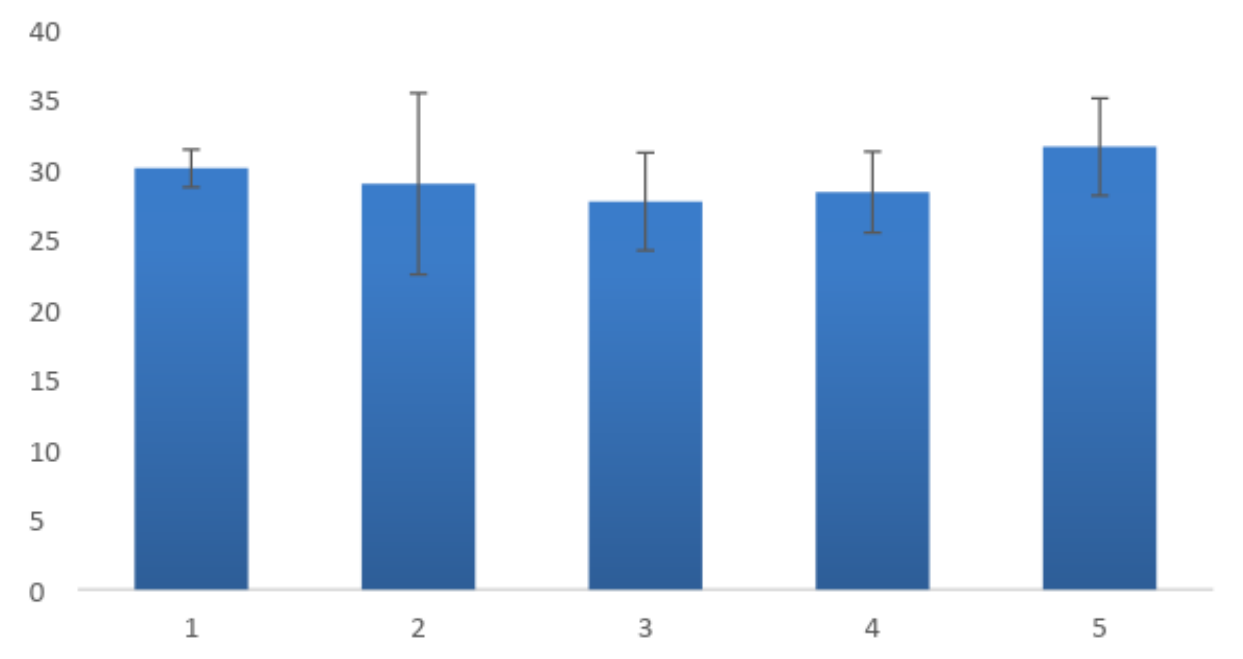

Figure (7): Comparison between degree of improvement after third month regarding to serum vitamin $D$ in oral vitamin $D$ group 


\section{DISCUSSION:}

After three months of treatment, the first group (topical calcipotriol) showed $52 \%$ full regrowth, $16 \%$ very good response, $4 \%$ some response, $12 \%$ poor response and $16 \%$ no response. The patient satisfaction was $68 \%$.

Baseline dermoscopic findings at the start for diagnosis of alopecia areata showed black dots in $100 \%$ of cases, yellow dots in $76 \%$, broken hair in $20 \%$ and tapering hairs in $44 \%$ of cases. After three months months of treatment, black dots appeared in $4 \%$ of cases, yellow dots in $12 \%$, short vellus hair in $60 \%$ of cases, terminal hairs in $68 \%$, but broken hair and tapering hairs were disappeared.

After three months of treatment, the second group (oral vitamin D) showed $20 \%$ full regrowth, $32 \%$ very good response, $28 \%$ some response, $12 \%$ poor response and $8 \%$ no response. The patient satisfaction was $52 \%$.

Baseline dermoscopic findings at the start for diagnosis of alopecia areata showed black dots in $100 \%$ of cases, yellow dots in $80 \%$, broken hair in $20 \%$ and tapering hairs in $48 \%$ of cases. After three months months of treatment, black dots appeared in $20 \%$ of cases, yellow dots in $16 \%$, short vellus hair in $40 \%$ of cases, terminal hairs in $52 \%$, but broken hair were disappeared. Tapering hairs were still present in $8 \%$ of cases. For our knowledge, our study was the first study use oral vitamin $D$ in the treatment of alopecia areata.

Based on the study of Amor et al in $\mathbf{2 0 1 0}$ who purposed to examine the role of vitamin $D$ in hair growth and the hair cycle; they discussed the possible implications of vitamin $D$ in the clinical care of patients with hair disorders. Initial observations indicate that vitamin D supplementation may be preventive in multiple sclerosis and diabetes mellitus. So an interventional clinical approach could be suggested according to the criteria of EBM (Evidence Based Medecine), also in the light of some our encouraging preliminary results suggest the possible important role of vitamin $D$ not only in the adjuvant therapy but also in decreasing the rate of relapses in these patients and perhaps in preventing the occurrence of the disease (d'Ovidio et al., 2013).

In our study, there was no statistically significant difference between topical calcipotriol cream and oral vitamin D regarding degree of improvement of alopecia after $1^{\text {st }}$ month, while there was statistically significant difference between topical calcipotriol cream and oral vitamin D regarding degree of improvement after $2^{\text {nd }}$ and $3^{\text {rd }}$ months ( $p$ $>0.05$ ) being better in topical calcipotriol group.

After three months months of treatment dermoscopic findings that explain signs of activity (Black dots, tapering hairs, yellow dots, broken hairs) of the disease were decreased, and signs of improvement (short vellus hairs, terminal hairs) were appeared. In topical calcipotriol group terminal hair was more than oral vitamin D group, in which signs of activity was still present in some cases. There was no statistically significant difference between topical calcipotriol $0.005 \%$ cream and oral vitamin D regarding patient satisfaction and there were no reported side effects of drugs. All patients of two groups were compliant to treatment and all patients 
with positive results had no recurrence after 3 months from stoppage of treatment.

Serum 25(OH)-D levels at $30 \mathrm{ng} / \mathrm{ml}$ was the cut-off values for Vitamin $D$ insufficiency (Elbassiony et al., 2016). Serum vitamin D levels were measured at baseline for all patients in our study, $68 \%$ of patients had vitamin D insufficiency.

In our study, there was no statistically significant difference between degree of improvement of alopecia in the third month regarding serum vitamin $D$. The

\section{CONCLUSION AND RECOMMENDATIONS:}

- Topical calcipotriol (68\% improvement) was better than oral vitamin D (52\%) in the treatment of mild and moderate alopecia areata.

- Topical calcipotriol may be effective in the treatment of mild and moderate patchy (not more than $40 \%$ of scalp distribution) alopecia areata.

- There is no relation between serum vitamin $\mathrm{D}$ and efficacy of treatment,

\section{REFERENCES:}

[1] Alsantali A (2011): Alopecia areata: a new treatment plan. Clinc, Cosm and Invest Dermatol; 4:107-115.

\section{[2] Amor KT, Rashid RM and} Mirmirani P (2010): Does D matter? The role of vitamin $\mathrm{D}$ in hair disorders and hair follicle cycling. Derma online $J ; 16$ (2): 3 .

[3] Brzezińska-Wcisło L, Bergler-Czop B, Lis-wiety $A$ and WcisłoDziadecka D (2014): New aspects of the treatment of alopecia areata. Postepy Dermatologii i Alergologii; 31(4): 262-265. mean serum vitamin $D$ for patients with full regrowth was $26.80 \pm 6.38$, for pateints with very good response was $27.14 \pm 4.00$, for pateints with some response was $26.33 \pm 4.95$, for pateints with poor response was $25.71 \pm 6.97$ and for pateints with no response was $26.28 \pm 5.25$.

It was meaning that response to treatment has no relation to baseline serum vitamin $D$, revealing that screening for vitamin D prior to treatment may be not recommended as we found in our study.

so it is not recommended to measure vitamin $\mathrm{D}$ prior to treatment.

- Oral vitamin D may be a main supplement in treatment of alopecia areata.

- Studies of larger scales are required to identify the vitamin $D$ receptor deficiency in alopecia areata.

[4] Çerman AA, Solak SS, Altunay I and Küçükünal NA (2015): Topical calcipotriol therapy for mild to moderate alopecia areata: A retrospective study. J Drugs Dermatol; 14(6):616-20.

[5] D'Ovidio R, Vessio M and d'Ovidio FD (2013): Reduced level of vitamin $\mathrm{D}$ in chronic/relapsing alopecia areata. 7th World Congress for Hair Research. 2-4.

[6] Dastani Z, Hivert MF, Timpson N, Perry JR, Yuan X, Scott RA, Henneman P, Heid IM, Kizer JR, 
Lyytikäinen LP, Fuchsberger C, Tanaka T, Morris AP, Small K, Isaacs A, Beekman M, Coassin S, Lohman K, Qi L, Kanoni S, Pankow JS, Uh HW, Wu Y, Bidulescu A and Rasmussen-Torvik LJ (2012): Novel loci for adiponectin levels and their influence on type 2 diabetes and metabolic traits: a multi-ethnic metaanalysis of 45, 891 individuals. PLoS Genet; 8(3): 1002607.

[7] Elbassiony SR, Tawhid Z, Ahmad HS and Sabry A (2016): Serum 25hydroxy vitamin D levels in Egyptian patients with rheumatoid arthritis: Association with disease activity, functional disability and radiological damage. Egy Rheumatol; 38(3): 133139.

[8] Galán-Gutiérrez M, RodríguezBujaldón A and Moreno-Giménez, JC (2009): Update on the Treatment of Alopecia Areata. Actas

dermosifiliográficas; 100(4): 266-276.

[9] Hordinsky MK (2013): Overview of Alopecia Areata. J Invest Dermatol Symp Proc; 16(1): 13-15.

[10] Narang T, Daroach $M$ and Kumaran MS (2017): Efficacy and safetyof topical calcipotriol in management of alopecia areata: A pilot study. DermatolTher; 18(5): 663679.

[11] Wadhwa B, Relhan V, Goel K, Kochhar AM, Garg VK (2015): Vitamin D and skin diseases: A review. Ind J Dermatol Venereol Leprol; 81(4): 344-355.

[12] Wadhwa B, Relhan V, Goel K, Kochhar AM, Garg VK (2015): Vitamin D and skin diseases: A review. Ind J Dermatol Venereol Leprol; 81(4): 344-355. 